\title{
THE EFFECT OF PUNCH-DIE CLEARANCE ON BLANKED EDGE QUALITY IN FINE BLANKING OF STEEL SHEETS
}

\begin{abstract}
In precision shearing there are different working principles oriented on good quality of blanked edge surface quality. In the case of fine blanking, indentation of the ring tooth at the blankholder into stock portion of material causes larger dishing than conventional shearing and the dishing can be changed from convex to concave according to the amount of indentation. Moreover, the amount of dishing changes during shearing owing to the working force and results in various topography of the blanked edge. This paper analyzes the effect of the punch-die gap on blanked edge quality in fine blanking. The objective is determination of basic mechanical properties of galvanized multiphase steel sheets with a thickness of 0.75 , 0.80 and $0.85 \mathrm{~mm}$ under the uniaxial tensile test, examination of the effect of the punch-die clearance on plastic zone height of stamped part edge and, finally, determination of the effect of material properties of blanked sheet metal on blanked edge quality.
\end{abstract}

Keywords: sheet metal, fine blanking, clearance, blanked edge quality

\section{Introduction}

Blanking is one of the basic processes in the sheet metal forming. It is one of the advanced technologies of processing materials and manufacturing products. In engineering practice, the shape of the product near the cut edge is by far the most important property. Blanking is a constrained shearing operation that involves elastic deflection, plastic deformation and fracture of the work material. In the blanking process, some factors such as the punch-die clearance, the tool geometry and the mechanical properties of the materials influence the quality of the cross-section and the dimension precision [1-5]. It is necessary to study the fracture of the metal and crack propagation to select rational process factors. Simple shearing is affected by the uneven action of plastic deformation

\footnotetext{
${ }^{1}$ Autor do korespondencji/corresponding author: Janka Majerníková, Technical University in Košice, 74 Mäsiarska St., 040-01 Košice, Slovakia, tel. +421 55 6023502, e-mail: janka.majernikova@tuke.sk

2 Emil Spišák, e-mail: emil.spisak@tuke.sk
} 
what makes the cut surface irregular. Because of that blanking methods have been improved and new technologies in the process of shearing have been developed. Using these technologies we can easier achieve higher geometric precision and surface quality. There are the following methods of fine blanking of parts: shaving, blanking with a curved cutting edge, the use of blanking tools with a tapered blank holder, reverses blanking, and fine blanking with a V-ring indenter [6-10]. Fine blanking with V-ring indenter technologies is designed in 1952 by the H. Schmid Company, successfully extended by Bosch [6] and patented by Schiess [7]. In conventional metal stamping only a punch and a die set is used. Fine blanking adds two more elements: a clamping or „stinger" plate to prevent die roll-off and a counter punch (ejector) to control deformation as the punch pushes through the plate (Fig. 1). In fine blanking with a V-ring indenter, the V-ring indenter presses into the sheet material close to the cut line, gripping the material on both sides of the cut. Compression stress occurs in the cutting zone and causes the plastic phase to affect the entire thickness of the blanked material, resulting in a quality blanked edge [3]. Thus, the part is smoothly removed from the strip.

Fine blanking is a specialized type of blanking in which the blank is sheared from the sheet stock by applying 3 separate forces - blanking force, holding force and ejector force (Fig. 1). Most of the equipment and setup for fine blanking is similar to conventional blanking. The fine blanking process resembles an extrusion process rather than the shearing process of conventional stamping. This results in a part with superior flatness, smooth edges, less roll-off and tighter form tolerances. The improved tolerance control results from die to punch clearances are much less than that of conventional stamping [9]. The sheet stock is still placed over a blanking die inside a hydraulic press and a blanking punch will impact the sheet to remove the blank. As it is mentioned above, this is done by the application of 3 forces. The first is a downward holding force applied to the top of the sheet. A clamping system holds a guide plate tightly against the sheet and is held in the place with an impingement ring, sometimes called a stinger that surrounds the perimeter of the blanking location. The second force is applied underneath the sheet, directly opposite the punch, by a „,cushion". This cushion provides a counter force during the blanking process and later ejects the blank. These two forces reduce bending of the sheet and improve the flatness of the blank. The final force is provided by the blanking punch impacting the sheet and shearing the blank into the die opening. In fine blanking, the clearance between the punch and the die is smaller and the blanking is performed at slower speeds. As a result, instead of the material fracturing to free the blank, the blank flows and is extruded from the sheet, providing a smoother edge. To manufacture parts in fine blanking quality, the following conditions have to be met: a press, a tool and a material.

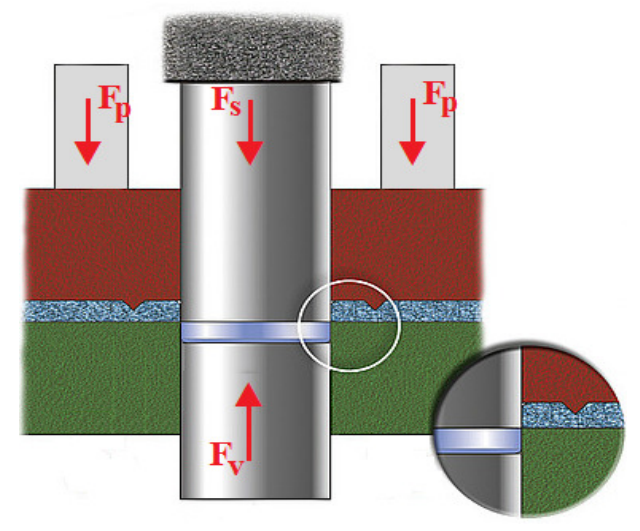


Fig. 1. Schematic of the fine blanking process with a V-ring indenter: $F_{P}$ - blanking punch force, $F_{V}$ - ejector force, $F_{S}-$ blanking force

This technique produces a part with better flatness, a smoother edge with minimal burrs, and tolerances as tight as $\pm 0.001 \mathrm{~mm}$. As a result, high quality parts can be blanked, so that they do not require any secondary operations. However, the additional equipment and tooling does add to the initial cost and makes fine blanking better suited to high volume production. The fine blanking has been used in automotive industry such as door locks, gear boxes, reclining seat adjusters, etc. Fine blanking refers to such methods of blanking of metal sheets and strips using cutting tools that produce a smooth edge, perpendicular to the sheet metal plane. Dimensions of blanks or punched holes are within tolerances that exceed the level of accuracy of conventional stamping by as much as two accuracy levels [1].

The fine blanking technology could be suitable for a wide range of materials, respectively steels with sufficient cold forming property and minimum yield strength. Ideal for fine blanking are low carbon steels and low-alloy steels. The decisive factor for the suitability of the material is its structure, which is affected by the content of carbon and alloying elements present and previous thermal processing. The raw material for fine blanked components is primarily rolled metal coils, although extruded and rolled strips are also used. In some cases nonmetallic materials are fine blanked. For the fine blanking it is necessary to use material with uniform: chemical composition, structure, dimensional accuracy, mechanical properties. The shape of the fragile components (cementite, pearlite etc.) in the material structure is also important for fine blanking.

The aim of this paper is to assess the suitability for fine blanking of four different galvanized multiphase steel sheets used in automobile industry.

\section{Experimental procedure}

Multiphase steel sheets were used for the experiment to evaluate the effect of the punch-die gap on blanked edge quality in fine blanking:

- micro-alloyed steel (H220PD Z100MBO), marked $M$, thickness $a_{0}=0.80 \mathrm{~mm}$, 
- transformation-induced plasticity steel (TRIP RAK40/70 Z100MBO), marked $T$, thickness $a_{0}=0.75 \mathrm{~mm}$,

- deep-drawing steel (DC06 BZE75/75PHOL), marked $Y$, thickness $a_{0}=0.75 \mathrm{~mm}$,

- deep-drawing steel (DC06 BZE75/75PHOL), marked $Z$, thickness $a_{0}=0.85 \mathrm{~mm}$.

Steel sheets types $M$ and $T$ were electrolytically galvanized on both sides, the zinc coating weight being $100 \mathrm{~g} / \mathrm{m}^{2}$. Deep-drawing steel sheets $Y$ and $Z$ were also zinc coated on both sides, the zinc coating weight being $75 \mathrm{~g} / \mathrm{m}^{2}$. Chemical compositions of experimental materials are shown in Table 1.

When the uniaxial tensile testing is concerned, tensile specimens of 240 $\mathrm{mm}$ gauge length and $12.5 \mathrm{~mm}$ width were prepared from strips cut at $0^{\circ}, 45^{\circ}$ and $90^{\circ}$ according to the rolling direction of the sheet. During experiments, we recorded simultaneously the tensile load, the current length and the current width of the specimens.

Table 1. Chemical composition of tested materials [\%]

\begin{tabular}{|c|c|c|c|c|c|c|c|c|c|c|}
\hline $\begin{array}{c}\text { Materia } \\
\mathbf{l}\end{array}$ & $\mathbf{C}$ & $\mathbf{M n}$ & $\mathbf{P}$ & $\mathbf{S}$ & $\mathbf{T i}$ & $\mathbf{S i}$ & $\mathbf{A l}$ & $\mathbf{C r}$ & $\mathbf{C u}$ & $\mathbf{N i}$ \\
\hline H220PD & 0.004 & 0.415 & 0.042 & 0.004 & 0.037 & 0.1 & 0.035 & 0.031 & 0.011 & 0.017 \\
\hline TRIP & 0.204 & 1.683 & 0.018 & 0.003 & 0.009 & 0.2 & 1.73 & 0.055 & 0.028 & 0.018 \\
\hline DC06 & 0.02 & 0.25 & 0.02 & 0.02 & 0.3 & - & - & - & - & - \\
\hline
\end{tabular}

An experimental shear cutting tool (Fig. 2) and a ZD 40 hydraulic press were used for fine blanking with a V-ring indenter. Replaceable top parts of the shear cutting tool enable adjustment of the following parameters in fine blanking with a V-ring indenter:

- the V-ring indenter size in the range of $0.5 \div 1.5 \mathrm{~mm}$,

- the distance between the V-ring indenter and the cut line is $1.2 \mathrm{~mm}$ to $2.0 \mathrm{~mm}$,

- the punch-die clearance ranges between 0 and $0.15 \mathrm{~mm}$.

In present experimental investigation at least five specimens fabricated from 50 × $250 \mathrm{~mm}$ steel sheets were sheared under following conditions:

- V-ring indenter height: $h=0.55 \mathrm{~mm}$,

- distance between the V-ring indenter and the cut line: $1.5 \mathrm{~mm}$,

- two punch-die clearances: 0.01 and $0.08 \mathrm{~mm}$.

The height of plastic zone on blanked strips edge surface was measured by an Olympus Bx FM microscope at the Department of Technologies and Materials. 
Fig. 2. Experimental shear cutting tool: 1 - support, 2 - upper plate, 3 - blanking punch, 4 - blanking die, 5 - blank holder, 6 - spring, 7 - ejector, 8 - guide plate

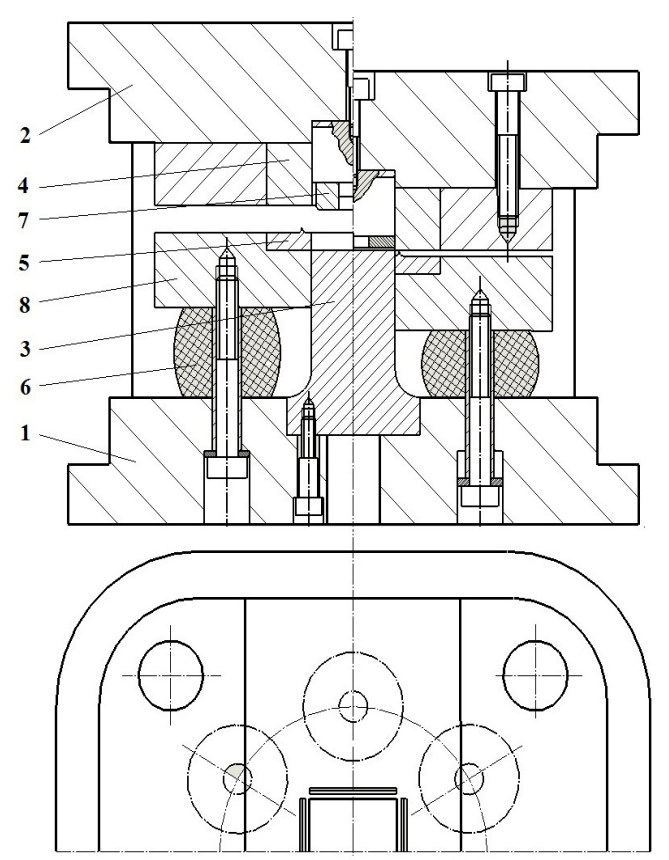

\section{Results and discussion}

The results of the uniaxial tensile test demonstrate visible difference in the value of mechanical parameters (Table 2 and 3), as well as flow characteristic (Fig. 3) depending on sheet material, especially in the case of the TRIP steel. Punch-die clearance has the largest effect on blanked edge quality. Therefore, its magnitude, regularity and stability become very important factors as well as the tool wears. Thanks to full clamping of a workpiece and the V-ring indenter on the blank holder, there are favorable stresses conditions in the shear cutting zone that enable high plastic deformation in this zone as well as crack avoidance.

Table 2. Mechanical properties of H220PD and TRIP steel sheets

\begin{tabular}{|c|c|c|c|c|c|c|}
\hline \multirow[b]{3}{*}{$\begin{array}{l}\text { Specimen } \\
\text { orientation }\end{array}$} & \multicolumn{6}{|c|}{ Sheet material } \\
\hline & \multicolumn{3}{|c|}{ H220PD } & \multicolumn{3}{|c|}{ TRIP } \\
\hline & $\begin{array}{c}\text { yield } \\
\text { stress } \\
R_{e} \\
{[\mathrm{MPa}]}\end{array}$ & $\begin{array}{c}\text { ultimate } \\
\text { strength } \\
\boldsymbol{R}_{m} \\
{[\mathrm{MPa}]} \\
\end{array}$ & $\begin{array}{c}\text { total } \\
\text { elongation } \\
\boldsymbol{A}_{\mathbf{8 0}} \\
{[\%]} \\
\%\end{array}$ & $\begin{array}{c}\text { yield } \\
\text { stress } \\
R_{e} \\
{[\mathrm{MPa}]}\end{array}$ & $\begin{array}{c}\text { ultimate } \\
\text { strength } \\
\boldsymbol{R}_{m} \\
{[\mathrm{MPa}]} \\
\end{array}$ & $\begin{array}{c}\text { total } \\
\text { elongation } \\
\boldsymbol{A}_{\mathbf{8 0}} \\
{[\%]} \\
\end{array}$ \\
\hline $0^{\circ}$ & 209 & 402 & 34.5 & 442 & 771 & 32.7 \\
\hline $45^{\circ}$ & 203 & 391 & 37.4 & 441 & 762 & 30.4 \\
\hline $90^{\circ}$ & 208 & 399 & 35.8 & 450 & 766 & 30.9 \\
\hline Mean value & 206 & 396 & 36.3 & 445 & 765 & 31.1 \\
\hline
\end{tabular}


Table 3. Mechanical properties of DC06 steel sheets

\begin{tabular}{|c|c|c|c|c|c|c|}
\hline \multirow[b]{3}{*}{$\begin{array}{c}\text { Specimen } \\
\text { orientation }\end{array}$} & \multicolumn{6}{|c|}{ Sheet material } \\
\hline & \multicolumn{3}{|c|}{ DC06 - Y } & \multicolumn{3}{|c|}{ DC06 - Z } \\
\hline & $\begin{array}{c}\text { yield } \\
\text { stress } \\
R_{e} \\
{[\mathrm{MPa}]}\end{array}$ & $\begin{array}{c}\text { ultimate } \\
\text { strength } \\
\boldsymbol{R}_{\boldsymbol{m}} \\
{[\mathrm{MPa}]} \\
\end{array}$ & $\begin{array}{c}\text { total } \\
\text { elongation } \\
\boldsymbol{A}_{80} \\
{[\%]} \\
\%]\end{array}$ & $\begin{array}{c}\text { yield } \\
\text { stress } \\
R_{e} \\
{[\mathrm{MPa}]}\end{array}$ & $\begin{array}{c}\text { ultimate } \\
\text { strength } \\
\boldsymbol{R}_{\boldsymbol{m}} \\
{[\mathrm{MPa}]} \\
\end{array}$ & $\begin{array}{c}\text { total } \\
\text { elongation } \\
\boldsymbol{A}_{80} \\
{[\%]} \\
\end{array}$ \\
\hline $0^{\circ}$ & 148 & 277 & 53.0 & 155 & 282 & 55.9 \\
\hline $45^{\circ}$ & 153 & 282 & 50.4 & 161 & 288 & 52.9 \\
\hline $90^{\circ}$ & 152 & 277 & 51.7 & 159 & 284 & 53.0 \\
\hline Mean value & 152 & 279 & 51.6 & 159 & 286 & 53.7 \\
\hline
\end{tabular}

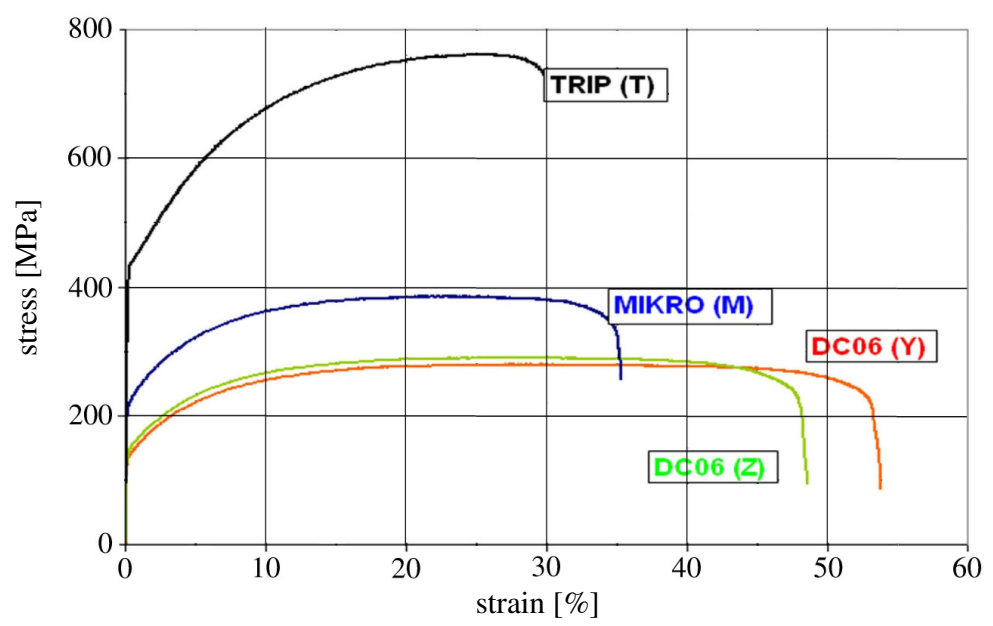

Fig. 3. Uniaxial tensile characteristics of steel sheets tested

According to the results of the plastic zone height measurements (Table 4), the plastic zone area decreases proportionally with clearance increasing. The largest value of the plastic zone height was observed in the case of the microalloyed steel sheet $M$, and the smallest in the case of the TRIP steel sheet $T$ (Fig. 4).

From careful observation and measurements of shared edge of strips it is noticed that in the case of fine blanking the relative plastic zone height $h_{v} / a_{0}$ differs considerably to the difference of material properties characterized by the ratio of the yield stress to ultimate strength (Table 5). The value of the $h_{v} / a_{0}$ index decrease with the value of the $R_{e} / R_{m}$ ratio increasing for both value of punch-die clearance applied (Fig. 5). A little deviation from linearity of such relation in the case of clearance of $0.01 \mathrm{~mm}$ could be a result of different thickness of the DC06 deep drawing steel sheet. 
Table 4. Plastic zone height of the sheet blanked for two different punch-die clearances: 0.01 and $0.08 \mathrm{~mm}$

\begin{tabular}{|c|c|c|c|c|c|}
\hline \multirow{2}{*}{$\begin{array}{c}\text { Sheet } \\
\text { material }\end{array}$} & \multirow{2}{*}{$\begin{array}{c}\text { Clearance } \\
{[\mathbf{m m}]}\end{array}$} & \multicolumn{4}{|c|}{$\begin{array}{c}\text { Plastic zone height } \\
\text { [mm] }\end{array}$} \\
\cline { 3 - 6 } & & $\boldsymbol{h}_{\boldsymbol{v 1}}$ & $\boldsymbol{h}_{\boldsymbol{v} \mathbf{2}}$ & $\boldsymbol{h}_{\boldsymbol{v} \mathbf{3}}$ & $\begin{array}{c}\text { average } \\
\boldsymbol{h}_{\boldsymbol{v}}\end{array}$ \\
\hline \multirow{2}{*}{$\mathrm{H} 220 \mathrm{PD}$} & 0.01 & 0.626 & 0.620 & 0.624 & 0.623 \\
\cline { 2 - 6 } & 0.08 & 0.504 & 0.508 & 0.508 & 0.507 \\
\hline \multirow{2}{*}{ TRIP } & 0.01 & 0.436 & 0.434 & 0.436 & 0.435 \\
\cline { 2 - 6 } & 0.08 & 0.324 & 0.329 & 0.348 & 0.334 \\
\hline \multirow{2}{*}{ DC06-Y } & 0.01 & 0.501 & 0.494 & 0.490 & 0.495 \\
\cline { 2 - 6 } & 0.08 & 0.423 & 0.430 & 0.423 & 0.425 \\
\hline \multirow{2}{*}{ DC06-Z } & 0.01 & 0.549 & 0.546 & 0.535 & 0.543 \\
\cline { 2 - 6 } & 0.08 & 0.440 & 0.444 & 0.453 & 0.446 \\
\hline
\end{tabular}
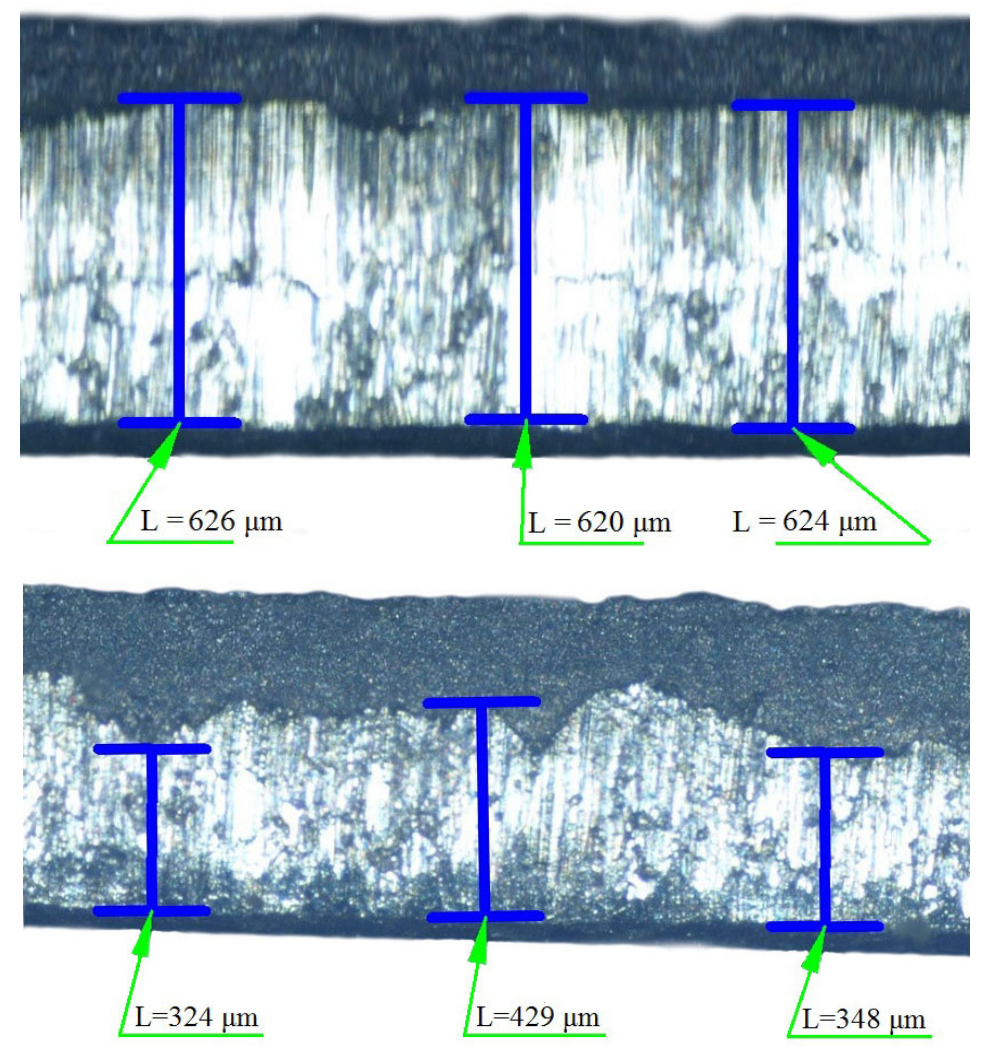

Fig. 4. Plastic zone height of sample: H220PD steel sheet blanked with $0.01 \mathrm{~mm}$ clearance (top) and TRIP steel sheet blanked with $0.08 \mathrm{~mm}$ clearance (bottom) 
Table 5. Relative plastic zone height $h_{v} / a_{0}$ dependence on sheet material index $R_{e} / R_{m}$

\begin{tabular}{|c|c|c|c|c|c|}
\hline $\begin{array}{c}\text { Sheet } \\
\text { material }\end{array}$ & $\begin{array}{c}\text { Sheet } \\
\text { thickness } \\
\boldsymbol{a}_{\mathbf{0}}\end{array}$ & $\begin{array}{c}\boldsymbol{R}_{\boldsymbol{e}} / \boldsymbol{R}_{\boldsymbol{m}} \\
\text { index }\end{array}$ & $\begin{array}{c}\text { Clearance } \\
{[\mathbf{m m}]}\end{array}$ & $\begin{array}{c}\boldsymbol{h}_{\boldsymbol{v}} \\
{[\mathbf{m m}]}\end{array}$ & $\boldsymbol{h}_{\boldsymbol{v}} / \boldsymbol{a}_{\mathbf{0}}$ \\
\hline \multirow{2}{*}{$\mathrm{H} 220 \mathrm{PD}$} & 0.80 & 0.529 & 0.01 & 0.623 & 0.779 \\
\hline \multirow{2}{*}{$\mathrm{DC} 06-\mathrm{Y}$} & 0.80 & & 0.08 & 0.507 & 0.663 \\
\hline \multirow{2}{*}{$\mathrm{DC} 06-\mathrm{Z}$} & 0.75 & 0.545 & 0.01 & 0.495 & 0.660 \\
\cline { 4 - 6 } & 0.75 & & 0.08 & 0.425 & 0.567 \\
\hline \multirow{2}{*}{$\mathrm{TRIP}$} & 0.85 & \multirow{2}{*}{0.556} & 0.01 & 0.542 & 0.638 \\
\cline { 4 - 6 } & 0.85 & & 0.08 & 0.446 & 0.525 \\
\cline { 4 - 6 } & 0.75 & \multirow{2}{*}{0.581} & 0.01 & 0.435 & 0.560 \\
\cline { 4 - 6 } & 0.75 & & 0.08 & 0.334 & 0.445 \\
\hline
\end{tabular}

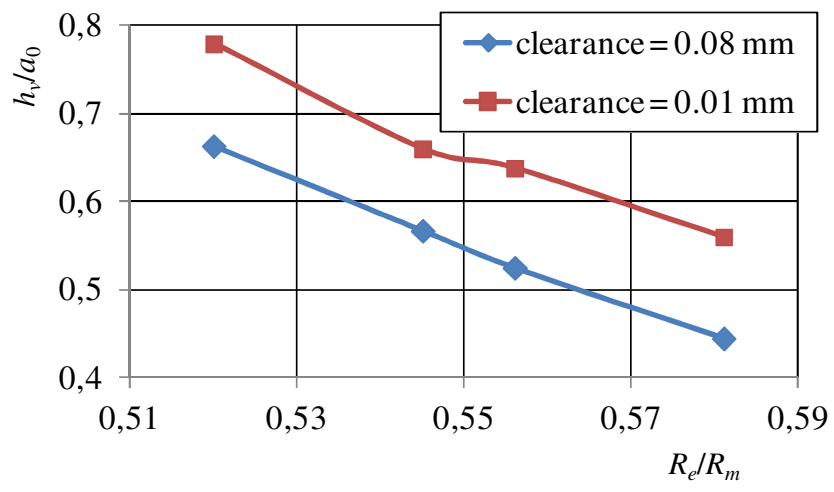

Fig. 5. Relative plastic zone height $h_{v} / a_{0}$ dependence on sheet material $R_{e} / R_{m}$ ratio

\section{Conclusion}

The results of the experiment indicate that in blanking of 0.75 to $0.85 \mathrm{~mm}$ thick galvanized multiphase steel sheets the punch-die clearance clearly affects blanked edge quality, evaluated in terms of the relation of plastic zone height to blanked material thickness index. For the all four types of sheet metal, the $h_{v} / a_{0}$ value was higher at the punch-die clearance of $0.01 \mathrm{~mm}$ than at $0.08 \mathrm{~mm}$. Taking into account mechanical properties (yield stress, ultimate strength, and total elongation) the experiments showed that the value of the $h_{\vee} / a_{0}$ blanked edge surface quality index decreases with the increase of the value of the $R_{e} / R_{m}$ ratio. The measured result leads to the conclusion that the same shear cutting tool can be used for fine blanking of all material tested when using $0.01 \mathrm{~mm}$ punch-die clearance. 


\section{References}

[1] Lange K.: Handbook of metal forming. McGraw-Hill Book Company, New York 1985.

[2] Erbel S., Kuczyński K., Marciniak Z.: Obróbka plastyczna. PWN, Warszawa 1981.

[3] Greškovič F., Lachváč J., Hrivňák A., Spišák E.: Evaluation of cutting of steel sheets. Zeszyty Naukowe Politechniki Rzeszowskiej Mechanics, 197 (2000), 109-114.

[4] Frącz W., Kut S., Mucha J., Stachowicz F.: Experimental investigation of blanking process using TiN coated tool materials. Kovarenstvi, 33 (2008), 124-126.

[5] Frącz W., Kut S., Stachowicz F.: Experimental and numerical investigation of steel sheet blanking with pre-bending. Kovarenstvi, 33 (2008), 121-123.

[6] Bosch F.: Fine blanking - practical handbook. Feintool AG, Lyss 1972.

[7] Schiess F.: The fine blanking process. Patent No. 371004, Germany 1992.

[8] Thipprakmas S.: Finite-element analysis of V-ring indenter mechanism in fine-blanking process. Materials Design, 30 (2009), 526-531.

[9] Kim Y.J., Kawk T.S., Bae W.B.: Finite element analysis on effect of die clearance on shear planes in fine blanking. J. Mat. Proc. Technol., 130-131 (2002), 462-468.

[10] Kwak T.S., Kim Y.J., Seo M.K., Bae W.B.: The effect of V-ring indenter on the sheared surface in the fine-blanking process of pawl. J. Mat. Proc. Technol., 143-144 (2003), 656-661.

\section{Acknowledgement}

The authors are grateful to APVV for support of experimental work under grant APVV0682-11 - Application of progressive tool coatings for in-creasing the effectiveness and productivity of forming sheets made of modern materials and the project VEGA 1/0396/11 - Research and optimization of evaluation methods of strength and plastic properties of thin tinplates.

\section{WPLYW LUZU NA JAKOŚĆ KRAWĘDZI PRZECIĘCIA W PROCESIE WYKRAWANIA DOKŁADNEGO BLACH STALOWYCH}

\section{Streszczenie}

Podczas wykrawania dokładnego wiele różnych parametrów wpływa na jakość powierzchni przecięcia. W przypadku wykrawania dokładnego wgniatanie występu pierścieniowego dociskacza w pakiet blach powoduje większe jej wyginanie w porównaniu z wykrawaniem konwencjonalnym. Profil wygięcia może zmieniać się z wypukłego na wklęsły w zależności od wielkości zagłębiania. Ponadto wielkość wygięcia profilu blachy zmienia się podczas procesu cięcia i zależy od siły wykrawania. Powoduje to wystąpienie różnej topografii na powierzchni przecięcia. W pracy przedstawiono analizę wpływu luzu na jakość krawędzi przecięcia w procesie wykrawania dokładnego. Celem badań jest określenie podstawowych parametrów mechanicznych galwanizowanych wielofazowych blach stalowych o grubości 0,$75 ; 0,80$ oraz $0,85 \mathrm{~mm}$ w próbie jednoosiowego 
rozciągania, badanie wpływu luzu na wysokość strefy uplastycznionej ciętego materiału oraz określenie wpływu właściwości materiałowych blachy na jakość krawędzi przecięcia.

Słowa kluczowe: blacha, wykrawanie dokładne, luz, jakość krawędzi przecięcia

DOI:10.7862/rm.2013.43

Otrzymano/received: $15.09 .2013 \mathrm{r}$.

Zaakceptowano/accepted: 22.11.2013 r. 